\title{
Estimation of genetic parameters for milk traits in Romanian local sheep breed
}

\section{Estimación de parámetros genéticos para características de la leche en la raza ovina local Rumano}

\author{
Pelmus RS,* Ph.D, Pistol GC, Ph.D, Lazar C, Ph.D, Gras MA, Ph.D, Ghita E, Ph.D.
}

National Research-Development Institute for Animal Biology and Nutrition, INCDBNA, Laboratory of Animal Biology, 1, Calea Bucuresti, 077015, Balotesti, Romania. *Correspondence: pelmus_rodica_ stefania@yahoo.com

Received: March 2013; Accepted: November 2013.

\begin{abstract}
Objective. Estimate the genetic parameters for milk traits in a Romanian local sheep population Teleorman Black Head. Material and methods. Records of 262 sheep belonging to 17 rams and 139 ewes were used in the study. The following traits were investigated: milk yield, fat yield, protein yield, fat percentage and protein percentage. The genetic parameters were estimated using the Restricted Maximum Likelihood method, with a model including maternal effects. Results. The results from our study revealed that direct heritability estimates were moderate for milk yield $(0.449)$, fat yield $(0.442)$, protein yield $(0.386)$ while for protein percentage $(0.708)$ and fat percentage $(0.924)$ were high. The high direct and maternal genetic correlation was between milk yield and protein yield $(0.979,0.973)$ and between protein yield and fat yield $(0.952,0.913)$ while the phenotypic correlation between the milk yield and fat yield $(0.968)$, the milk yield and protein yield (0.967), fat yield and protein yield (0.936) was high and positive. Conclusions. The genetic parameters are important in selection program on this breed for genetic improvement.
\end{abstract}

Key Words: Genetic improvement, milk production characteristics, ovinos (Source: $C A B$ ).

\section{RESUMEN}

Objetivo. Estimar los parámetros genéticos para características de la leche en una población de ovinos locales Rumanos Teleorman cabeza negra. Materiales y métodos. En el estudio se utilizaron registros de 262 animales pertenecientes a 17 carneros y 139 ovejas. Se investigaron los siguientes rasgos: producción de leche, producción de grasa, producción de proteína, porcentaje de grasa y porcentaje de proteína de la leche. Los parámetros genéticos fueron estimados mediante el método de Máxima Verosimilitud Restringida, con un modelo que incluye efectos maternos. Resultados. Los resultados de este estudio revelaron que la heredabilidad directa fue moderada para la producción de leche $(0.449)$, producción de grasa $(0.442)$ y producción de proteína $(0.386)$ mientras que para el porcentaje de proteína $(0.708)$ y el porcentaje de grasa $(0.924)$ fueron altos. La alta correlación genética directa y materna se produjo entre la producción de leche y la producción de proteína $(0.979,0.973)$ y entre la producción de proteína y de grasa $(0.952,0.913)$ mientras que la correlación fenotípica entre la producción de leche y de grasa $(0.968)$, la producción de leche y proteína (0.967), la producción de proteína y de grasa (0.936) fue alta y positiva. Conclusiones. Los parámetros genéticos son importantes en el programa de selección de esta raza para el mejoramiento genético.

Palabras clave: Características de la producción de leche, mejoramiento genético, sheep (Fuente: CAB). 


\section{INTRODUCCIÓN}

Los ovinos Teleorman cabeza negra son una raza local rumana con un alto potencial para la producción de leche. Carta et al (1) ha demostrado que esta razas ovinas locales tienen varios rasgos importantes como: rusticidad, resistencia y adaptabilidad a diferentes condiciones ambientales. La raza de ovinos Teleorman cabeza negra fue inscrita en la base de datos nacional y de la FAO para los recursos zoogenéticos.

La estimación de los parámetros genéticos de los ovinos locales Teleorman cabeza negra es necesaria para estimar el valor genético de los animales y determinar los objetivos de cría. Es necesario un programa de reproducción de la raza Teleorman cabeza negra para la producción de leche.

Muchos autores han utilizado el método de Máxima Verosimilitud Restringida (REML) para estimar los parámetros genéticos de los rasgos de producción en razas ovinas; Oravcova et al (2), Komprej et al (3) y Bauer et al (4).

El objetivo de este estudio fue estimar los parámetros genéticos para las características de la leche de Teleorman cabeza negra usando el método de Máxima Verosimilitud Restringida (REML), ajustando un modelo lineal de Rasgos Maternos a las características de producción de leche.

\section{MATERIALES Y MÉTODOS}

Animales y muestras biológicas. Se obtuvieron muestras de leche de 262 ovejas pertenecientes a la raza local Teleorman cabeza negra, de la granja experimental del Instituto Nacional de Investigación y Desarrollo de Biología y Nutrición Animal, Balotesti, Rumania. En la tabla 1 se presentan las características de los ovinos Teleorman cabeza negra.

La leche de cada ordeño fue medida individualmente. Se realizaron un total de 4 días de pruebas utilizando el método ICAR B4 (30 días) para determinar la producción de leche; Carta et al (1). La duración de la lactancia total fue de 172 días en la población de ovinos Teleorman cabeza negra.

Determinación de índices de calidad de la leche. Los porcentajes totales de grasa y proteína fueron determinados utilizando el analizador Ekomilk M (Bulteh 2000 Ltd, EON Trading LLC, Delaware, EE.UU.).

\section{INTRODUCTION}

The Teleorman Black Head sheep is a Romanian local breed with high potential for milk production. Carta et al (1) have shown that this local sheep breeds have several important traits such as: rusticity, resistance and adaptability to different environmental conditions. The teleorman black head sheep breed is enlisted in the national and in FAO database for animal genetic resources.

The estimation of the genetic parameters for the teleorman black head local sheep is necessary in order to estimate the breeding value of the animals and to determine the breeding objectives. A breeding program for milk production is necessary for teleorman black head breed.

Many authors have used restricted maximum likelihood (REML) method for estimating the genetic parameters of production traits in sheep breeds Oravcova et al (2), Komprej et al (3), Bauer et al (4).

The objective of this study was to estimate the genetic parameters for milk traits of the teleorman black head using Restricted Maximum Likelihood (REML) method, fitting a Maternal Trait linear model for milk production traits.

\section{MATERIALS AND METHODS}

Animals and biological samples. Milk samples were obtained from 262 sheep belonging to the local breed, teleorman black head, from the experimental farm of National ResearchDevelopment Institute for Animal Biology and Nutrition, Balotesti, Romania. The characteristics of teleorman black head sheep are presented in table 1.

Table 1. The Characteristics of teleorman black head.

\begin{tabular}{lc}
\hline \multicolumn{1}{c}{ Specification } & Number \\
\hline Total records per trait & 262 \\
Litter size fixed effect levels & 2 \\
Lamb gender fixed effect levels & 2 \\
Ewes & 262 \\
Sires (rams) & 17 \\
Dams (ewes) & 139 \\
\hline Total number of animals & 418 \\
\hline
\end{tabular}

The milk from each milking was measured individually. A total of 4 test-days were performed using the ICAR method B4 (30 days) to determine the milk yield Carta et al (1). The length of the total lactation was 172 days in the teleorman black head sheep population. 
Análisis estadístico. La estimación de los parámetros genéticos se realizó mediante el método de Máxima Verosimilitud Restringida (REML); el software utilizado fue MATLAB Student 5.3, usando un modelo lineal de Rasgos Maternos. El número de iteraciones necesarias para que las estimaciones convergieran fue: 113 iteraciones para producción de leche, 112 para producción de grasa, 117 para producción de proteína, 68 para el porcentaje de grasa y 99 iteraciones para el porcentaje de proteína. Los criterios de convergencia fueron:

$100 \cdot\left(1-\sqrt{\frac{C_{1}}{C_{2}}}\right)$

$G=\begin{array}{cc}\sigma_{a}^{2} A & \sigma_{m} A \\ \sigma_{m} A & \sigma_{m}^{2} A\end{array}$

$\mathrm{G}=$ matriz de varianza y covarianza genética aditiva para efecto animal $\mathrm{G}=$ cálculo inicial

$\mathrm{G}_{1}=$ calculado en primera iteración

$\mathrm{H}=\mathrm{G}_{1}-\mathrm{G}$

$\mathrm{C}_{1}=\mathrm{H}^{2}$

$\mathrm{C}_{2}=\mathrm{G}_{1}{ }^{2}$

En notación matricial, (Mrode y Thompson, (5)) el modelo es el siguiente:

$y=X b+Z a+W m+S p e+e$

Donde:

$y=$ vector de observaciones, $b=$ vector de efectos fijos, $a=$ vector de efectos animales aleatorios, $m=$ vector de efectos genéticos maternos aleatorios, $p e=$ vector de efectos ambientales permanentes y $e=$ vector de efectos residuales aleatorios.

$X, Z, W$ y $S$ son matrices de incidencia que hacen referencia al desempeño animal, los efectos fijos, los efectos directos, los efectos maternos y los efectos ambientales permanentes.

Se asume que:

$\operatorname{var}\left[\begin{array}{c}a \\ m \\ p \\ e\end{array}\right]=\left[\begin{array}{cccc}\sigma_{a}^{2} A & \sigma_{m} A & 0 & 0 \\ \sigma_{m} A & \sigma_{m}^{2} A & 0 & 0 \\ 0 & 0 & I \sigma_{p}^{2} & 0 \\ 0 & 0 & 0 & I \sigma_{e}^{2}\end{array}\right]$

Donde:

$A$ es la matriz de parentesco entre animales; $I$ es la matriz de identidad; $\sigma^{2}$ es la varianza genética aditiva de efectos directos, $\sigma_{m}^{2}$ la varianza genética aditiva de efectos maternos, $\sigma_{\mathrm{am}}$ la
Determination of milk quality indices. The total percentages of fat and protein were determined using the Ekomilk $M$ analyser (Bulteh 2000 Ltd, EON Trading LLC, Delaware, USA).

Statistical analysis. The estimation of the genetic parameters was done with the restricted maximum likelihood (REML) method; the software used was MATLAB Student 5.3, using a Maternal Trait linear model. The number of iterations needed for estimates to converge was: 113 iterations for milk yield, 112 for fat yield, 117 for protein yield, 68 for fat percentage and 99 iterations for protein percentage. The convergence criteria was:

$100 \cdot\left(1-\sqrt{\frac{C_{1}}{C_{2}}}\right)$

$G=\begin{array}{cc}\sigma_{a}^{2} A & \sigma_{m} A \\ \sigma_{m} A & \sigma_{m}^{2} A\end{array}$

$\mathrm{G}=$ additive genetic variance and covariance matrix for animal effect $\mathrm{G}=$ initial calculated

$\mathrm{G}_{1}=$ calculated at first iteration

$\mathrm{H}=\mathrm{G}_{1}-\mathrm{G}$

$\mathrm{C}_{1}=\mathrm{H}^{2}$

$\mathrm{C}_{2}=\mathrm{G}_{1}{ }^{2}$

In matrix notation, (Mrode and Thompson, (5)) the model is:

$y=X b+Z a+W m+S p e+e$

Where:

$y=$ the vector of observations, $b=$ the vector of the fixed effects, $a=$ the vector of the random animal effects, $m=$ the vector of the random maternal genetic effects, $p e=$ the vector of the permanent environmental effects and $e=$ the vector of the random residual effects.

$X, Z, W$ and $S$ are the incidence matrices referring to animal performance, to the fixed effects, to the direct effects, to the maternal effects and to the permanent environmental effects.

It is assumed that:

$$
\operatorname{var}\left[\begin{array}{c}
a \\
m \\
p \\
e
\end{array}\right]=\left[\begin{array}{cccc}
\sigma_{a}^{2} A & \sigma_{m} A & 0 & 0 \\
\sigma_{m} A & \sigma_{m}^{2} A & 0 & 0 \\
0 & 0 & I \sigma_{p}^{2} & 0 \\
0 & 0 & 0 & I \sigma_{e}^{2}
\end{array}\right]
$$

Where:

$A$ is the kinship matrix between animals; $I$ is the identity matrix; $\sigma^{2}{ }_{a}$ is the additive genetic 
covarianza genética aditiva entre los efectos directos y maternos, $\sigma^{2}$ e es la varianza casada por los efectos ambientales permanentes, $\sigma^{2}$ es la varianza del error residual.

De acuerdo con el objetivo de este estudio, se estimaron los siguientes parámetros genéticos:

Heredabilidad genética $\left(h_{a}{ }^{2}=\sigma^{2}{ }_{a} / \sigma_{p}{ }^{2}\right)$, donde $\sigma_{p}{ }^{2}$ es la variancia fenotípica.

Heredabilidad materna $\left(h_{m}{ }^{2}=\sigma_{m}^{2} / \sigma_{p}^{2}\right)$.

Covarianza entre efectos directos y maternos como proporción de la varianza fenotípica $\left(\sigma_{\mathrm{am}} /\right.$ $\sigma_{p}^{2}$ )

Heredabilidad total

$h_{T}^{2}=\frac{\sigma_{a}^{2}+0.5 \sigma_{m}^{2}+1.5 \sigma_{m}}{\sigma_{p}^{2}}$

(Wilham qouted por Ghafouri-Kesbi y Baneh (6))

Donde:

$\mathrm{h}_{\mathrm{T}}^{2}$ es la heredabilidad total, y $\sigma_{\mathrm{P}}^{2}$ la variancia fenotípica.

Cociente entre el ambiente materno permanente y la varianza fenotípica $\left(\mathrm{c}^{2}\right)$.

$r_{a m}$ correlación genética entre los efectos directos y maternos.

$$
r_{o n}=\frac{\sigma_{m}}{\sqrt{\sigma_{a}^{2} \cdot \sigma_{m}^{2}}}
$$

En el presente estudio, la parte fija del modelo incluyó el tamaño de la camada y el sexo de los corderos. Los efectos aleatorios correspondieron a los efectos genéticos directos, los efectos genéticos maternos y los efectos ambientales permanentes.

Las correlaciones genéticas directas entre rasgos se estimaron de forma aproximada mediante la correlación de los valores genéticos de los ovinos para estos rasgos; las correlaciones genéticas maternas fueron estimadas de manera aproximada mediante la correlación de los efectos genéticos maternos para las características estudiadas, mientras que las correlaciones fenotípicas se estimaron mediante la correlación de los valores fenotípicos de las ovejas para estos rasgos. variance for the direct effects, $\sigma^{2}{ }_{m}$ the additive genetic variance for the maternal effects, $\sigma_{a m}$, the additive genetic covariance between the direct and maternal effects, $\sigma^{2}{ }_{p e}$ is the variance due the permanent environmental effects, $\sigma^{2}{ }^{\prime}$ is the variance of the residual error.

According to the objective of this paper the following genetic parameters were estimated:

The direct heritability $\left(h_{a}{ }^{2}=\sigma_{a}^{2} / \sigma_{p}{ }^{2}\right)$, where $\sigma_{p}{ }^{2}$ is the phenotypic variance.

The maternal heritability $\left(h_{m}{ }^{2}=\sigma_{m}^{2} / \sigma_{p}{ }^{2}\right)$

The covariance between direct and maternal effects as proportion of the phenotypic variance $\left(\sigma_{a m} / \sigma_{p}^{2}\right)$

The total heritability

$h_{T}^{2}=\frac{\sigma_{a}^{2}+0.5 \sigma_{m}^{2}+1.5 \sigma_{m}}{\sigma_{p}^{2}}$

(Wilham qouted by Ghafouri-Kesbi and Baneh (6))

Where:

$\mathrm{h}^{2}$ is the total heritability, and $\sigma^{2}$ is the phenotypic variance.

The ratio of the maternal permanent environment to phenotypic variance $\left(c^{2}\right)$.

$r_{a m}$ the genetic correlation between the direct and maternal effects

$r_{\text {om }}=\frac{\sigma_{m}}{\sqrt{\sigma_{a}^{2} \cdot \sigma_{m}^{2}}}$

In the present study, the fixed part of the model included the litter size and sex of lambs. The random effects were the direct genetic effects, the maternal genetic effects and the permanent environmental effects.

The direct genetic correlations between the traits were approximate estimated by the correlation of the breeding values of the sheep for these traits; the maternal genetic correlations were approximate estimated by the correlation of the maternal genetic effects for the studied traits, while the phenotypic correlations were estimated by the correlation between the phenotypic values of the sheep for these traits. 


\section{RESULTADOS}

En la tabla 2 se presenta el promedio de los rasgos de leche de ovinos Teleorman cabeza negra en la primera lactancia.

En la tabla 3 se muestran las estimaciones de los componentes de covarianza, heredabilidad directa, heredabilidad materna, correlación genética directa y materna y fracción de la varianza total debido a efectos ambientales maternos permanentes para los rasgos de la leche.

En este estudio, la varianza genética aditiva directa para la producción de leche representa el $44.9 \%$ de la varianza fenotípica, mientras que la varianza genética materna y la varianza ambiental materna permanente el $22.1 \%$ y el $4.4 \%$, respectivamente. La varianza genética aditiva directa para la producción de grasa es el $44.2 \%$ de la varianza fenotípica. Al mismo tiempo, la varianza genética materna y la varianza ambiental materna permanente fue del $20.5 \%$ y del $4.3 \%$, respectivamente. La varianza genética aditiva directa para la producción de proteína representa el $38.6 \%$ de la varianza fenotípica, mientras que la varianza genética materna y la varianza materna permanente corresponden al $21.4 \%$ y $4.4 \%$, respectivamente. La varianza genética aditiva directa para el porcentaje de grasa representa el $92.4 \%$ de la varianza fenotípica. La varianza genética materna y la varianza ambiental materna permanente corresponde al $24 \%$ y al $3.7 \%$, respectivamente. Para el porcentaje de proteína, la varianza genética aditiva directa representa el $70.8 \%$ de la varianza fenotípica mientras que la varianza genética materna y la varianza ambiental materna permanente fue del $23.1 \%$ y del $4.1 \%$. La covarianza entre los

\section{RESULTS}

The average performances for milk traits for Teleorman Black Head sheep at the first lactation are presented in table 2 .

Table 2. Average of milk traits for Teleorman Black Head sheep.

\begin{tabular}{lcccc}
\hline Item & Mean & $\begin{array}{c}\text { Standard } \\
\text { Error }\end{array}$ & $\begin{array}{c}\text { Standard } \\
\text { deviation }\end{array}$ & $\begin{array}{c}\text { Variation } \\
\text { coefficient } \\
\text { (\%) }\end{array}$ \\
\hline Milk yield $(\mathrm{I})$ & 103.72 & 2.84 & 46.12 & 44.46 \\
Fat yield $(\mathrm{kg})$ & 6.79 & 0.20 & 3.20 & 47.14 \\
Protein yield $(\mathrm{kg})$ & 5.94 & 0.17 & 2.81 & 47.26 \\
\hline
\end{tabular}

The estimates of covariance components, direct heritability, maternal heritability, direct-maternal genetic correlation and fraction of total variance due to maternal permanent environmental effects for milk traits are shown in table 3.

In this study, the direct additive genetic variance for milk yield represents $44.9 \%$ from phenotypic variance while the maternal genetic variance and the maternal permanent environmental variance are $22.1 \%$ and $4.4 \%$, respectively. The direct additive genetic variance for fat yield is $44.2 \%$ from the phenotypic variance. At the same time, the maternal genetic variance and maternal permanent environmental variance are $20.5 \%$, $4.3 \%$ respectively. The direct additive genetic variance for protein yield represents $38.6 \%$ from the phenotypic variance while the maternal genetic variance and the maternal permanent variance are $21.4 \%$ and $4.4 \%$ respectively. The direct additive genetic variance for fat percentage represents $92.4 \%$ from the phenotypic variance. The maternal genetic variance and the maternal permanent environmental variance are $24 \%$ and $3.7 \%$, respectively. For protein percentage, the direct additive genetic variance represents $70.8 \%$

Table 3. Estimates of covariance components and genetic parameters for milk yield, fat yield, protein yield, fat and protein percentage.

\begin{tabular}{|c|c|c|c|c|c|}
\hline Item & Milk yield & Fat yield & Protein yield & Fat (\%) & Protein (\%) \\
\hline$\sigma_{a}^{2}$ & 1094.500 & 5.198 & 3.446 & 0.573 & 0.295 \\
\hline$\sigma_{m}^{2}$ & 537 & 2.412 & 1.908 & 0.149 & 0.096 \\
\hline$\sigma_{\mathrm{am}}$ & -480.200 & -2.322 & -1.501 & -0.256 & -0.133 \\
\hline$\sigma_{p e}^{2}$ & 106.243 & 0.511 & 0.394 & 0.023 & 0.017 \\
\hline$\sigma_{e}^{2}$ & 1177.100 & 5.953 & 4.682 & 0.132 & 0.141 \\
\hline$\sigma_{p}^{2}$ & 2434.643 & 11.752 & 8.929 & 0.621 & 0.416 \\
\hline$h_{a}^{2}$ & $0.449 \pm 0.244$ & $0.442 \pm 0.242$ & $0.386 \pm 0.143$ & $0.924 \pm 0.409$ & $0.708 \pm 0.334$ \\
\hline$h_{m}{ }^{2}$ & $0.221 \pm 0.166$ & $0.205 \pm 0.160$ & $0.214 \pm 0.163$ & $0.240 \pm 0.172$ & $0.231 \pm 0.209$ \\
\hline$c^{2}$ & 0.044 & 0.043 & 0.044 & 0.037 & 0.041 \\
\hline$\sigma_{a m} / \sigma_{p}^{2}$ & -0.197 & -0.198 & -0.168 & -0.412 & -0.319 \\
\hline$r_{\mathrm{am}}$ & -0.626 & -0.655 & -0.585 & -0.876 & -0.790 \\
\hline $\mathrm{h}_{\mathrm{T}}^{2}$ & $0.264 \pm 0.180$ & $0.249 \pm 0.175$ & $0.241 \pm 0.173$ & $0.424 \pm 0.236$ & $0.346 \pm 0.169$ \\
\hline
\end{tabular}

$\sigma^{2}$ direct additive genetic variance, $\sigma^{2}$ maternal genetic variance, $\sigma$ direct-maternal additive genetic covariance, $\sigma^{2}$ maternal permanent environmental variance, $\sigma_{e}^{2}$ residual variance, $h_{a}^{2}$ direct heritability, $h_{m}^{2}$ maternal heritability, $c^{2}=\sigma_{p e}^{2} / \sigma_{p}^{2}$ ratio of maternal permanent environmental variance to phenotypic variance, $\sigma_{\mathrm{am}} / \sigma_{\mathrm{p}}{ }^{2}$ covariance between direct and maternal effects as proportion to phenotypic variance, $r_{\mathrm{am}}$ genetic correlation between direct and maternal effects, $h_{\mathrm{T}}^{2}$ total heritability 
efectos genéticos directos y maternos para todos los rasgos fue negativa.

Las estimaciones de la heredabilidad directa fueron moderadas para la producción de leche, producción de grasa y de proteína mientras que fueron mayores para el porcentaje de proteína y el porcentaje de grasa. La heredabilidad directa para estos rasgos fue mayor que la heredabilidad materna.

La correlación genética aditiva directa-maternal fue negativa y sobre todo mayor para todos los rasgos.

La varianza ambiental materna permanente como proporción de la varianza fenotípica $\left(c^{2}\right)$ fue igual para la producción de leche y la producción de proteína $(0.044)$.

Las estimaciones de heredabilidad fueron bastante variables, lo que sugiere que los parámetros específicos de raza y rasgos de leche son necesarios para estimar los valores genéticos y predecir la respuesta a la selección.

En la tabla 4 se muestra la estimación de las correlaciones fenotípicas, las correlaciones genéticas directas y las correlaciones genéticas maternas entre los rasgos. La correlación genética directa entre la producción de leche y porcentaje de grasa fue baja y positiva (0.009), así como la producción de leche y el porcentaje de proteína (0.007). Se han obtenido correlaciones genéticas moderadas y positivas entre el porcentaje de grasa y el porcentaje de proteína y entre el porcentaje de grasa y la producción de grasa. La alta correlación genética directa se produjo entre la producción de leche y la producción de proteína $(0.979)$, la producción de leche y la producción de grasa (0.977) y entre la producción de proteína y la producción de grasa (0.952). La correlación genética entre los efectos maternos para el porcentaje de grasa y la producción de leche y entre la producción de leche y el porcentaje de proteína fue baja y positiva, mientras que la correlaciones genéticas maternas entre la producción de leche y la producción de grasa, la producción de leche y la producción de proteína, la producción de proteína y la producción de grasa fueron altas y positivas. Se han obtenido correlaciones genéticas maternas moderadas y positivas entre el porcentaje de grasa y el porcentaje de proteína y entre el porcentaje de grasa y la producción de grasa.

La correlación fenotípica entre la producción de leche y el porcentaje de grasa y entre la producción de leche y el porcentaje de proteína fue baja y positiva, mientras que la correlación from phenotypic variance while the maternal genetic variance and the maternal permanent environmental variance are $23.1 \%$ and $4.1 \%$. The covariance between the direct and the maternal genetic effects for all the traits was negative.

Direct heritability estimates were moderate for milk yield, fat yield and protein yield while for protein percentage and fat percentage were greater. The direct heritability for these traits was greater than the maternal heritability.

The direct-maternal additive genetic correlation was negative and mostly greater for all traits.

The maternal permanent environmental variance as a proportion of the phenotypic variance $\left(c^{2}\right)$ was the same for milk yield and protein yield (0.044).

The heritability estimates were quite variable, suggesting that the parameters specific to milk traits and breed are necessary when estimating the breeding values and when predicting the response to selection.

Table 4 shows the estimation of the phenotypic correlations, of the direct genetic correlations and of the maternal genetic correlations between the traits. The direct genetic correlation between the milk yield and fat percentage was low and positive (0.009), as was the milk yield and protein percentage (0.007). Moderate and positive genetic correlations have been obtained between the fat percentage and protein percentage and between the fat percentage and fat yield. The high direct genetic correlation was between milk yield and protein yield (0.979), milk yield and fat yield $(0.977)$ and between protein yield and fat yield (0.952). The genetic correlation between the maternal effects for the milk yield and fat percentage and between milk yield and

Table 4. Phenotypic and genotypic correlation for the milk traits.

\begin{tabular}{llccc}
\hline \multicolumn{1}{c}{ Trait 1 } & \multicolumn{1}{c}{ Trait 2 } & $\mathbf{r}_{\mathbf{d}}$ & $\mathbf{r}_{\mathbf{m}}$ & $\mathbf{r}_{\mathbf{p}}$ \\
\hline Milk yield & Fat (\%) & $0.009 \pm 0.346$ & $0.038 \pm 0.518$ & $0.064 \pm 0.043$ \\
Milk yield & Fat yield & $0.977 \pm 0.017$ & $0.911 \pm 0.092$ & $0.968 \pm 0.011$ \\
Milk yield & Protein (\%) & $0.007 \pm 0.357$ & $0.028 \pm 0.618$ & $0.069 \pm 0.043$ \\
Milk yield & Protein yield & $0.979 \pm 0.013$ & $0.973 \pm 0.028$ & $0.967 \pm 0.011$ \\
Fat (\%) & Protein (\%) & $0.297 \pm 0.294$ & $0.348 \pm 0.500$ & $0.336 \pm 0.041$ \\
Fat (\%) & Protein yield & $0.117 \pm 0.367$ & $0.121 \pm 0.514$ & $0.127 \pm 0.043$ \\
Fat (\%) & Fat yield & $0.334 \pm 0.309$ & $0.330 \pm 0.468$ & $0.353 \pm 0.041$ \\
Fat yield & Protein (\%) & $0.145 \pm 0.351$ & $0.150 \pm 0.577$ & $0.191 \pm 0.043$ \\
Protein yield & Fat yield & $0.952 \pm 0.029$ & $0.913 \pm 0.090$ & $0.936 \pm 0.015$ \\
Protein yield & Protein (\%) & $0.297 \pm 0.269$ & $0.240 \pm 0.553$ & $0.299 \pm 0.042$ \\
\hline
\end{tabular}

$r$ direct genetic correlation between trait 1 and trait $2, r$ maternal genetic correlation between trait 1 and trait $2, r_{p}$ phenotypic correlation between trait 1 and trait 2 . 
fenotípica entre la producción de leche y la producción de grasa, la producción de leche y la producción de proteína, la producción de grasa y la producción de proteína fue alta y positiva. Se han obtenido correlaciones fenotípicas moderadas y positivas entre el porcentaje de grasa y el porcentaje de proteína y entre el porcentaje de grasa y la producción de grasa.

\section{DISCUSIÓN}

La producción de leche es uno de mayores rasgos de selección en la población de ovinos. Las estimaciones de heredabilidad obtenidas en el presente estudio son consistentes con aquellas reportadas para diversas poblaciones.

El valor de la heredabilidad total para la producción de leche de las ovejas en este estudio (0.264) fue similar a la heredabilidad total de la producción diaria de leche estimada por Bauer et al (4) para varias razas ovinas (East Friesian, Lacaune, Sumavska) entre 0.17 y 0.30 y Rupp et al (7) (0.28) y fue mayor que el valor (0.11) reportado por Komprej et al (3) y el valor de la heredabilidad (0.21) reportado por Legarra et al (8). Los valores de la heredabilidad para el contenido de grasa $(0.424)$ y el contenido de proteína $(0.346)$ en este estudio fueron mayores que los valores ( 0.08 para el contenido de grasa y 0.10 para el contenido proteínico) reportados por Komprej et al (3) en tres razas de ovinos lecheros eslovenos (Bovec, Bovec Mejorado e Istria Pramenka) y Alvarez et al (9) $(0.09,0.25)$.

La heredabilidad para el contenido de grasa y proteína y la producción de grasa y proteína en este estudio fue mayor que el valor reportado por De Vries et al (10). Las bajas estimaciones para $\mathrm{c}^{2}$ obtenidas en el presente estudio $(0.044)$ sugieren que los efectos maternos fueron causados por efectos genéticos aditivos maternos. Las estimaciones de la correlación genética entre los efectos directos y maternos en los rasgos de la leche eran generalmente altas y consistentemente negativas. En este estudio, la correlación entre los efectos genéticos directos y maternos para la producción de leche fue negativa y alta. En el presente estudio, las correlaciones genéticas entre la producción de leche y grasa, la producción de leche y proteína fueron positivas, altas y similares a los valores reportados por Ugarte (11).

Los resultados de nuestro estudio revelaron que las estimaciones de la heredabilidad directa protein percentage was low and positive, while the maternal genetic correlations between milk yield and fat yield, milk yield and protein yield, protein yield and fat yield were high and positive. Moderate and positive maternal genetic correlations have been obtained between the fat percentage and protein percentage and between the fat percentage and fat yield.

The phenotypic correlation between the milk yield and fat percentage and between the milk yield and protein percentage was low and positive, while the phenotypic correlation between the milk yield and fat yield, the milk yield and protein yield, fat yield and protein yield was high and positive. Moderate and positive phenotypic correlations have been obtained between the fat percentage and protein percentage and between the fat percentage and fat yield.

\section{DISCUSSION}

The milk yield is one of the major selection traits in sheep population. The heritability estimates obtained in the present study are in agreement with those reported for various populations.

The value of the total heritability for milk yield of the sheep from this study $(0.264)$ was similar with the total heritability of daily milk yield estimated by Bauer et al (4) for various breeds (East Friesian, Lacaune, Sumavska) sheep between 0.17 and 0.30 and Rupp et al (7) (0.28) and was larger than the value ( 0.11 ) reported by Komprej et al (3) and the value of the heritability $(0.21)$ reported by Legarra et al (8). The values of the heritability for fat content $(0.424)$ and protein content $(0.346)$ in this study were larger than the values $(0.08$ for fat content and 0.10 for protein content) reported by Komprej et al (3) in three Slovenian dairy sheep breeds (Bovec, Improved Bovec and Istrian Pramenka) and Alvarez et al $(9)(0.09,0.25)$.

The heritability for fat and protein content and fat and protein yield in the present study was larger than the value reported by De Vries et al (10). The low estimates for $\mathrm{c}^{2}$ obtained in the present study $(0.044)$ suggest that maternal effects were due to maternal additive genetic effects. The genetic correlation estimates between direct and maternal effects on the milk traits were generally high and consistently negative. In this study the correlation between the direct and maternal genetic effects for milk yield was negative and high. In the present study the genetic correlations between milk yield and fat yield, milk yield and protein yield were positive, high and similar with the values reported by Ugarte (11). 
fueron moderadas para la producción de leche, la producción de proteína, la producción de grasa y el porcentaje de proteína, mientras que las mismas fueron altas para el porcentaje de grasa. La elevada correlación genética directa y materna se produjo entre la producción de leche y proteína y entre la producción de proteína y grasa, mientras que la correlación fenotípica entre la producción de leche y grasa, la producción de leche y proteína, la producción de grasa y proteína fue alta y positiva. En conclusión, los parámetros genéticos son muy importantes en el programa de selección de esta raza.

\section{Agradecimientos}

Este estudio fue fianciado por CNCSIS-UEFISCDI Proyecto No.56/ PNII/TE, 2010-2013.
The results from our study revealed that direct heritability estimates were moderate for milk yield, protein yield, fat yield and protein percentage, while for fat percentage were high. The high direct and maternal genetic correlation was between milk yield and protein yield and between protein yield and fat yield, while the phenotypic correlation between the milk yield and fat yield, the milk yield and protein yield, fat yield and protein yield was high and positive. In conclusion the genetic parameters are very important in selection program on this breed.

\section{Acknowledgements}

This work was financially supported from CNCSISUEFISCDI Project no.56/ PNII/TE, 2010-2013.

\section{REFERENCES}

1. Carta A, Casu S, Salaris S. Invited review: Current state of genetic improvement in dairy sheep. J Dairy Sci 2009; 92:5814-5833.

2. Oravcova $M$, Margetin $M$, Peskovicova $D$, Dano J, Milerski M, Hetenyi L et al. Factors affecting milk yield and ewe's lactation curves estimated with test-day models. Czech J Anim Sci 2006; 11:483-490.

3. Komprej A, Gorjanc G, Kompan D, Kovac M. Covariance components by a repeatability model in Slovenian dairy sheep using test-day records. Czech J Anim Sci 2009; 9:426-434.

4. Bauer J, Milerski M, Pribyl J, Vostry L. Estimation of genetic parameters and evaluation of testday milk production in sheep. Czech J Anim Sci 2012; 57:522-528.

5. Mrode RA, Thompson R. Maternal Trait Models: Animal and Reduced Animals Models. Linear models for the prediction of animal Breeding Values. Cabi Publishing UK; 2005.

6. Ghafouri-Kesbi F, Baneh H. Genetic parameters for direct and maternal effects on growth traits of sheep. Arch Tierz 2012; 55(6):603-611.
7. Rupp R, Lagriffoul G, Astruc JM, Barilet F. Genetic Parameters for milk Somatic Cell Scores and Relationship with production traits in Franch Lacaune Dairy Sheep. J Dairy Sci 2003; 86:1476-1481.

8. Legarra A, Ugarte E. Genetic parameters of Udder Traits, Somatic Cell Score and Milk Yield in Laxta Sheep. J Dairy Sci 2005; 88:2238-2245.

9. Alvarez L, Gutierrez-Gill B, San Primitivo F, De la Fuente FL, Arranz JJ. Influence of prion protein genotypes on milk production traits in spanish Churra Sheep. J Dairy Sci 2006; 89:1784-1791.

10. De Vries F, Hamann H, Drogemuller C, Ganter M, Distl O. Analysis of associations between the prion protein genotypes and production traits in east friesian milk sheep. J Dairy Sci 2005; 88:392-398.

11. Ugarte E. The breeding program of Laxta breed. Biotech Anim Husbandry 2007; 23(56):97-111. 